\title{
Isolation and Characterization of Lactic Acid Bacteria from Banana Pseudostem
}

\author{
Shriniketan Puranik ${ }^{1 *}$, K.B. Munishamanna ${ }^{2}$ and K.S. Sruthy ${ }^{1}$ \\ ${ }^{I}$ Department of Agriculture Microbiology, University of Agricultural Sciences, GKVK, \\ Bengaluru-65, India \\ ${ }^{2}$ AICRP on PHET Scheme, UAS, GKVK, Bengaluru- 65, India \\ *Corresponding author
}

\section{A B S T R A C T}

\begin{tabular}{|c|}
\hline Keywords \\
\hline $\begin{array}{l}\text { Banana } \\
\text { pseudostem, Lactic } \\
\text { acid bacteria }\end{array}$ \\
\hline Article Info \\
\hline $\begin{array}{l}\text { Accepted: } \\
\text { 04 February } 2019 \\
\text { Available Online: } \\
10 \text { March } 2019\end{array}$ \\
\hline
\end{tabular}

\section{Introduction}

Mainly lignocellulose constituents contribute to the overall property of plant fibers (Saira $e t$ al., 2007). In addition to water, the banana pseudostem comprises several polymers such as cellulose, hemicellulose, pectin and lignin that constitute fibers with good mechanical properties. Banana bast fibers have been widely recognized for their good quality over synthetic fibers and are used to make clothing, clothing and home furnishings (Uma et al., 2005). These chemical compositions may vary depending on age, variety, weather,

\begin{abstract}
Banana pseudostem comprises several polymers such as cellulose, hemicellulose, pectin and lignin that constitute fibers with good mechanical properties. These sugars can be used for production of various organic acids and alcohol. With the availability of such huge biomass as substrate, a wide range of microorganisms like bacteria and fungi grow on it. Lactic acid bacteria can grow on such sugars and can be isolated from banana pseudostem. In present study, lactic acid bacteria (LAB) were isolated from banana pseudostem core using MRS agar. The pseudo stem central core harbored the highest LAB population of $20.1 \times 10^{3} \mathrm{cfu} / \mathrm{g}$. The isolates showed varied morphological characteristics like oval, creamy, pin head colonies on MRS agar plates. LAB isolates also assimilated different carbon sources like glucose, dextrose, sucrose, fructose and lactose. Such isolates can further be used for fermentation studies with pseudostem as substrate.
\end{abstract}

geographical location, etc. It is very important to know the chemical composition and mechanical properties of the fibers in the manufacturing of composites, textiles and pulp and paper (Abdul Khalil et al., 2006; Li et al., 2010). The banana pseudostem contains 2- 3\% starch of good quality and it can be readily extracted (Subrahmanyan et al., 1957). The moisture content of the feedstock affects all supply chain elements such as collection, storage, pre-processing, handling and transportation (Bardiya et al., 1996). Such high moisture content might cause instability of the biomass material because it biodegrades 
easily with the action of microbes. This can cause problems with dry matter loss and hygiene due to the release of the pungent odor and fungi production (Van Loo and Koppejan, 2008). This also harbors lactic acid bacteria and yeasts which can be isolated for efficient strains degrading pseudostem.

Lactobacilli are Gram-positive, non-sporeforming, catalase-negative rods belonging to the group of lactic acid bacteria (Bernardeau et al., 2008). Lactobacillus acidophilus is one of the major species of this genus found in human and animal intestines. They are able to create equilibrium between beneficial and harmful microbiota of the guts if present in sufficient numbers, as probiotics (Tannock, 1999 and Suskovic et al., 2000). There are many reports of isolation of lactic acid bacteria from various fruits, vegetables and their wastes. Mayer and Hillebrandt (1997) reported characterization of six isolates done from Lactobacillus genera viz., Lactobacillus brevis, L. casei, L. delbrueckii, L. helveticus, L. lactis and L. plantarum with a population of $10^{7}-10^{9}$ cells/g wet pulp of potato. The study concluded that potato pulp was one of the agricultural waste products obtained in high quantities during starch production containing starch, cellulose, hemicelluloses, pectin, proteins, free amino acids and salts. Kim et al., (1998) isolated lactic acid bacterial strains from kimchi, viz., Lactobacillus acidophilus, L. plantarum, Leuconostoc mesenteroides, with or without Saccharomyces cerevisiae and were used as inoculants in fruit-vegetable juice fermentation.

Sulochana et al., (2002) detected Lactobacilli from various natural home-made fermented materials. Lactobacillus maltaromicus, $L$. plantarum and L. amylophilus were the three prominent mesophillic and homofermentative isolates obtained from vegetables, cereals, millets. Lactobacillus maltaromicus has exhibited greater physiological potentiality giving maximum amount of lactic acid and high yield. Lade et al., (2006) isolated two strains of lactic acid bacteria from vegetable waste containing spoiled cabbage and cucumber and were screened for bacteriocin properties. Zlatica Kohajdova and others (2006) studied on lactic acid fermentation of some vegetable juices and suitability of various kinds of vegetables (cabbage, tomatoes, pumpkin and courgette) for the preparation of vegetable juices processed by lactic acid fermentation was tested. Authors reported that all tested vegetable juices have proven to be suitable substrates for lactic acid fermentation. Papamanoli and others (2003) isolated a total of 147 lactic acid bacteria from two types of naturally fermented dry sausages at four different stages of the ripening process studied in order to select the most suitable strains according to their technological characteristics including probiotic properties and antimicrobial activity against food-borne pathogens. El-Rahim and others (2017) isolated seven LAB strains based on physiological and biochemical characteristics. They identified the strains as Lactobacillus casei, Lactobacillus plantarum, Lactobacillus brevis, Streptococcus lactis, Streptococcus bovis, and Streptococcus thermophilus from three traditional Egyptian dairy products (Karish cheese, buttermilk and whey).

Thus, for the degradation of banana pseudostem, isolation of lactic acid bacteria was done at Post Harvest Engineering Scheme, University of Agricultural Sciences, GKVK, Bangalore. These isolates were to be used for further microbial processing of banana pseudostem.

\section{Materials and Methods}

Different parts of banana pseudo stem and fruits were collected from different places for enumeration and isolation lactic acid bacteria. The populations of lactic acid bacteria were 
enumerated in samples by standard plate count method using de Mann, Rogosa and Sharpe's medium (MRS) medium with composition as mentioned below.

Mann, Rogosa and Sharpe's agar (De Mann et al., 1960)

$\begin{array}{ll}\text { Oxoid peptone } & : 10.00 \mathrm{~g} \\ \text { Meat extract } & : 10.00 \mathrm{~g} \\ \text { Yeast extract } & : 5.00 \mathrm{~g} \\ \mathrm{~K}_{2} \mathrm{HPO}_{4} & : 2.00 \mathrm{~g} \\ \text { Diammonium citrate } & 2.00 \mathrm{~g} \\ \text { Glucose } & : 20.00 \mathrm{~g} \\ \text { MgSO4 } & : 0.58 \mathrm{~g} \\ \text { MnSO4 } & : 0.25 \mathrm{~g} \\ \text { Sodium acetate } & : 5.00 \mathrm{~g} \\ \text { Agar } & : 18 \mathrm{~g} \\ \text { Distilled water } & : 1000 \mathrm{ml} \\ \text { pH } & : 6.2-6.6\end{array}$

Similarly, different lactic acid bacteria were isolated from different sources of banana pseudo stem core samples. The source and details of isolates is given in Table 1a.

The lactic acid bacterial isolates were further purified and characterized by standard procedures. These pure cultures were observed under the microscope after staining by Gram staining for lactic acid bacteria and were compared with reference strain of Lactobacillus acidophilus MTCC 10307 (RLAB 4).

\section{Identification of lactic acid bacterial isolates}

Identification of lactic acid bacterial isolates was done by studying their morphological and biochemical tests.

\section{Morphological identification}

Lactic acid bacteria, on de Mann, Rogosa and Sharpe's media, formed characteristic colonies which were used as a tool for the preliminary identification. Each isolate was streaked on MRS medium and incubated for three days.

\section{Gram staining}

Lactic acid bacterial isolates were studied for their cell morphology and Gram reaction. Gram staining was done using $24 \mathrm{hr}$ old cultures. A thin smear of bacterial culture was made on a clean slide. Smear was air-dried and heat fixed. Smear was covered with crystal violet dye for 30 seconds and washed with distilled water. Then the smear was covered with Gram's iodine solution for 60 seconds. Iodine solution was washed off with 95 per cent ethyl alcohol. Ethyl alcohol was added drop by drop, until no more colour flows from the smear. Slides were washed with distilled water and drained. Safranin was applied to smear for 30 seconds as counter stain, washed with distilled water and blot dried with absorbent paper. Slides were examined microscopically using oil immersion objective (Aneja, 2012).

\section{Characterization of lactic acid bacteria}

- Gram staining

- Carbohydrate fermentation

- Catalase activity

- Gelatin hydrolysis

\section{Biochemical characterization}

\section{Catalase activity}

A loop full of $24 \mathrm{hr}$ old culture suspension was placed on a clear glass slide to which a drop of freshly prepared hydrogen peroxide (3 per cent) was mixed and observed for the occurrence of effervescence or bubbles.

\section{Gelatin hydrolysis}

Bacterial isolates were inoculated on gelatin agar plates using pour plate method and 
incubated for 48 hours. Later the plates were flooded with 12.5 per cent mercuric chloride solution to observe the formation of clear zones around the colonies.

\section{Acid and gas production}

The bacterial isolates were tested for acid and gas production by inoculating to five $\mathrm{ml}$ presterilized glucose broth in test tubes containing Durham's tube and bromocresol purple (15 ml/L 0.04 per cent solution) as $\mathrm{pH}$ indicator (Seeley and Vandemark, 1970). The tubes were incubated for seven days at $30^{\circ} \mathrm{C}$. The accumulation of gas in the Durham's tube was taken as positive for gas production and change in color of medium to yellow was taken as positive for acid production.

\section{Results and Discussion}

The experimental results of isolation and characterization of lactic acid bacterial strains is as follows.

\section{Enumeration of microbial population in different parts of banana plant}

The population of lactic acid bacteria in different parts of banana is presented in Table 1b. The lactic acid bacterial (LAB) population was assessed in different parts of banana plant and it was found that the least lactic acid bacterial population was observed in pseudo stem fibre. The pseudo stem central core harbored the highest LAB population of $20.1 \mathrm{x}$ $10^{3} \mathrm{cfu} / \mathrm{g}$. The results indicated that the pseudo stem central core had more population of bacteria compared to other parts.

\section{Isolation and identification of lactic acid bacteria}

\section{Isolation}

Lactic acid bacteria were isolated using de Mann, Rogosa and Sharpe's (MRS) medium.
The results pertaining to isolates from different banana pseudo stem sources are presented in Table 2. All the lactic acid bacterial isolates including reference strain of Lactobacillus acidophilus MTCC 10307 (RLAB 4) were subjected to morphological and biochemical tests to confirm their identity.

\section{Identification}

\section{Colony morphology}

All the lactic acid bacterial isolates formed characteristic cream, smooth, round, oval submerged colonies on de Mann, Rogosa and Sharpe's medium along with the standard reference strain Lactobacillus acidophilus MTCC 10307 except for isolate BPSLAB 2 and BPSLAB 3 which showed spreading type colonies (Plate 1).

\section{Microscopic examination}

The lactic acid bacterial isolates were further examined for their shape and Gram reaction under microscope (Plate 2). The results showed that all lactic acid bacterial isolates including reference strain were Gram positive. BPSLAB 1 and reference strain RLAB 4 showed rod shaped cells whereas BPSLAB 2 and BPSLAB 3 showed diplococcoid cells (Table 2).

\section{Catalase activity}

Results related to catalase activity by the lactic acid bacterial isolates were presented in the Table 3. The data revealed that all the isolates showed negative for catalase activity indicating that isolates showed similar characteristics as that of Lactobacillus spp.

\section{Biochemical characteristics}

The colonies that appeared after $48 \mathrm{hrs}$ on Mann, Rogosa and Sharpe's (MRS) medium were cream, smooth, oval submerged colonies. 
The isolates and reference strain of lactic acid bacteria underwent several biochemical tests for their identification. The results in Table 3 revealed that all the lactic acid bacterial isolates including reference strain showed negative for gelatin liquefaction, spore and dextran production. All the lactic acid bacterial isolates were tested for their confirmation of the acid production on bromocresol green ethanol agar plate. The yellow zone around the colonies indicated the acid production by the isolates indicated the characteristics as that of Lactobacillus spp.

\section{Utilization of different carbon sources}

The results on assimilation of different carbon sources by reference strain Lactobacillus acidophilus (RLAB 4) and other isolates are presented in Table 4. The results revealed that all lactic acid bacterial isolates showed good assimilation of glucose and dextrose. Medium assimilation of sucrose, fructose and lactose was observed in all lactic acid bacterial strains. BPSLAB 3 showed medium lactose assimilation whereas, BPSLAB1, BPSLAB 2 and RLAB 4 showed good assimilation of lactose.

The results of the studies on isolation and characterization of lactic acid bacteria from various parts of banana plant are discussed here.

\section{Enumeration of lactic acid bacteria from different parts of banana plant}

Enumeration of lactic acid bacteria was carried out by standard plate count method. The pseudo stem central core harbored the highest LAB population of $20.1 \times 10^{3} \mathrm{cfu} / \mathrm{g}$. This may be due to the nutrients present in the fruit stimulates or enrich the growth and activity of bacteria. Similar observation was made by de Mann et al., 1960 stating that MRS agar media has growth stimulating effect that selectively enriches the growth and population of lactic acid bacteria. The presence of lactic acid bacteria in different sources has been supported by several researchers in different fruits and vegetables / wastes (Zlatica Kohajdova et al., 2006).

\section{Isolation and characterization of lactic acid bacteria}

In the present study, three lactic acid bacteria were isolated from banana pseudo-stem of different sources using MRS agar medium and named as BPSLAB 1, BPSLAB 2 and BPSLAB 3. Lactobacillus acidophilus MTCC 10307 (RLAB 4) was used as a reference strain. The LAB isolates showed the characteristics of cream, smooth, round, oval submerged colonies. Lactic acid bacterial cell morphology can be determined by following simple staining and gram-staining technique by which it was confirmed that all were gram positive. They were not able to hydrolyze gelatin and were catalase negative. They were tested for gas and acid production from lactose and observations showed that isolates were homo-fermentative; they produced only acid and did not produce any gas during growth. Muyanja et al., (2003) isolated lactic acid bacteria from bushera (Ugandan traditional fermented beverage). Tamminen et al., (2004) isolated bacteria from fermented cucumber and was identified as Lactobacillus plantarum and Leuconostoc sp., Isitua and Ibeh (2010) isolated lactic acid bacteria from pineapple (Ananascomosus) wastes.

The growth and activity of lactic acid bacteria differs with genera and species of lactic acid bacterial strains. The maximum growth on MRS broth was noticed with Lactobacillus acidophilus MTCC 10307 whereas isolate BPSLAB 2 showed the least growth. These results are in concurrence with the findings of Deepak (1994) who reported that growth and activity varies with isolates. 
Table.1a Lactic acid bacterial isolates from banana pseudo stem collected from various areas

\begin{tabular}{|c|c|c|}
\hline Sl. No. & Lactic acid bacterial isolates & Source \\
\hline $\mathbf{1}$ & BPSLAB 1 & PG Boys' Hostel orchard \\
$\mathbf{2}$ & BPSLAB 2 & Nagenahalli, Bengaluru North \\
$\mathbf{3}$ & BPSLAB 3 & Nagenahalli, Bengaluru North \\
\hline
\end{tabular}

Note: BPSLAB 1: Banana Pseudo Stem Lactic acid bacteria isolate 1

BPSLAB 2: Banana Pseudo Stem Lactic acid bacteria isolate 2

BPSLAB 3: Banana Pseudo Stem Lactic acid bacteria isolate 3

Table.1b Lactic acid bacterial population (cfu/g of part) in different parts of banana fruit and pseudo stem

\begin{tabular}{|c|c|}
\hline Part of the plant & LAB $(\mathbf{c f u} / \mathrm{g})$ \\
\hline Banana fruit & $2.1 \times 10^{3}$ \\
\hline Banana peel & $1.2 \times 10^{3}$ \\
\hline Pseudo stem fibre & $1.1 \times 10^{3}$ \\
\hline Pseudo stem core & $20.1 \times 10^{3}$ \\
\hline
\end{tabular}

Table.2 Morphological characteristics of lactic acid bacterial isolates

\begin{tabular}{|c|c|c|c|}
\hline Sl. No. & Isolate & $\begin{array}{c}\text { Colony characteristics on MRS } \\
\text { media }\end{array}$ & $\begin{array}{l}\text { Microscopic } \\
\text { observation }\end{array}$ \\
\hline 1 & BPSLAB 1 & $\begin{array}{l}\text { Oval, white, submerged, pin head } \\
\text { colonies }\end{array}$ & Rods, in chains \\
\hline 2 & BPSLAB2 & Spreading, raised, little slimy & Diplococci \\
\hline 3 & BPSLAB3 & $\begin{array}{c}\text { Dull creamish, very slimy, spreading } \\
\text { type }\end{array}$ & Diplococci \\
\hline 4 & RLAB 4 & $\begin{array}{c}\text { submerged, white, circular, pin head } \\
\text { size }\end{array}$ & $\begin{array}{l}\text { Rods, in chains or } \\
\text { single }\end{array}$ \\
\hline
\end{tabular}

Note: BPSLAB 1: Banana Pseudo Stem Lactic acid bacterial isolate 1

BPSLAB 2: Banana Pseudo Stem Lactic acid bacterial isolate 2

BPSLAB 3: Banana Pseudo Stem Lactic acid bacterial isolate 3

RLAB 4: Reference Lactic Acid Bacteria Lactobacillus acidophilus

Table.3 Biochemical characterization of lactic acid bacterial isolates

\begin{tabular}{|c|c|c|c|c|c|c|c|c|}
\hline $\begin{array}{c}\text { Sl. } \\
\text { No. }\end{array}$ & Isolates & $\begin{array}{c}\text { Gram's } \\
\text { reaction }\end{array}$ & $\begin{array}{c}\text { Catalase } \\
\text { activity }\end{array}$ & \multicolumn{2}{c|}{$\begin{array}{c}\text { Glucose } \\
\text { Utilization }\end{array}$} & $\begin{array}{c}\text { Gelatin } \\
\text { hydrolysis }\end{array}$ & $\begin{array}{c}\text { Spore } \\
\text { production }\end{array}$ & $\begin{array}{c}\text { Dextran } \\
\text { production }\end{array}$ \\
\hline $\mathbf{1}$ & BPSLAB 1 & + & - & + & - & - & - & - \\
\hline $\mathbf{2}$ & BPSLAB 2 & + & - & + & - & - & - & - \\
\hline $\mathbf{3}$ & BPSLAB 3 & + & - & + & - & - & - & - \\
\hline $\mathbf{4}$ & RLAB 4 & + & - & + & - & - & - & - \\
\hline
\end{tabular}

Note: A- Acid production, G- Gas production

BPSLAB 1: Banana Pseudo Stem Lactic acid bacterial isolate 1

BPSLAB 2: Banana Pseudo Stem Lactic acid bacterial isolate 2

BPSLAB 3: Banana Pseudo Stem Lactic acid bacterial isolate 3

RLAB 4: Reference Lactic Acid Bacteria Lactobacillus acidophilus (+- Positive; -- Negative) 
Table.4 Utilization of carbon sources by lactic acid bacterial isolates

\begin{tabular}{|c|c|c|c|c|c|c|}
\hline Sl. No. & Isolates & Glucose & Dextrose & Sucrose & Fructose & Lactose \\
\hline $\mathbf{1}$ & BPSLAB 1 & ++ & ++ & + & + & ++ \\
\hline $\mathbf{2}$ & BPSLAB 2 & ++ & ++ & + & + & ++ \\
\hline $\mathbf{3}$ & BPSLAB 3 & ++ & ++ & + & + & + \\
\hline $\mathbf{4}$ & RLAB 4 & ++ & ++ & + & + & ++ \\
\hline
\end{tabular}

Note: BPSLAB 1: Banana Pseudo Stem Lactic acid bacterial isolate 1 BPSLAB 2: Banana Pseudo Stem Lactic acid bacterial isolate 2 BPSLAB 3: Banana Pseudo Stem Lactic acid bacterial isolate 3 RLAB 4: Reference Lactic Acid Bacteria Lactobacillus acidophilus (++ - good utilization; +- medium assimilation)

Plate.1 Growth of lactic acid bacterial isolate on MRS agar medium

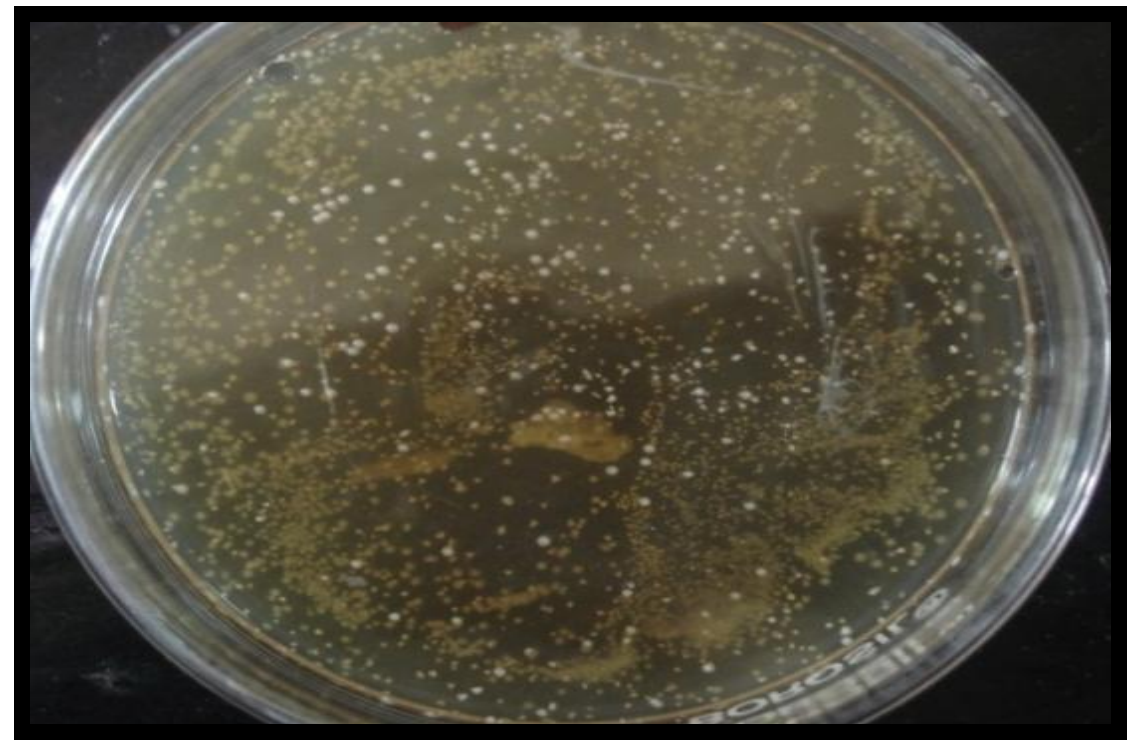

Plate.2 Microphotograph of reference lactic acid bacteria Lactobacillus acidophilus

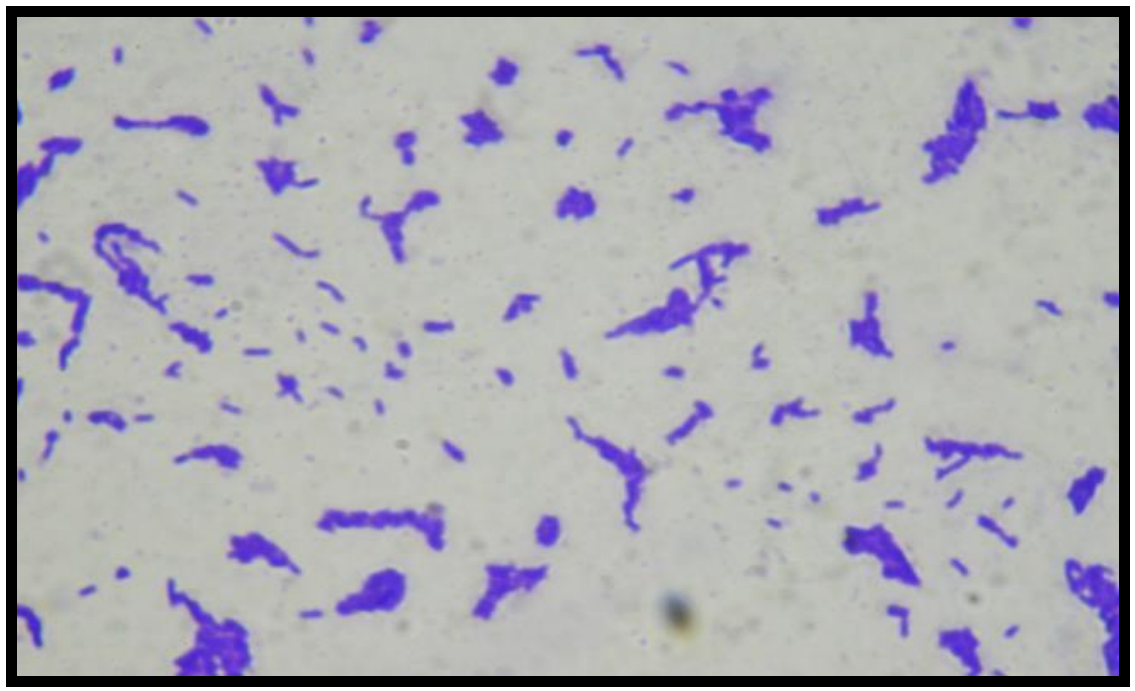


Lactic acid bacteria can assimilate different carbon sources like glucose, dextrose, sucrose, fructose and lactose. In the present study, all the isolates and reference strains showed good assimilation of glucose and dextrose and medium assimilation of sucrose, fructose and lactose. These results were in agreement with the findings of Hammes et al., (1992) in different lactic acid bacteria.

In conclusion, in the study, isolation of lactic acid bacteria from banana pseudo stem core was attempted and isolates were identified based on the colony morphology and characterized using various parameters. Three isolates of lactic acid bacteria BPSLAB 1, BPSLAB 2 and BPSLAB 3 were isolated and compared with reference strain Lactobacillus acidophilus MTCC 10307 (RLAB 4). All the lactic acid bacterial isolates formed characteristic cream, smooth, round, oval, submerged/raised colonies on de Mann, Rogosa and Sharpe's medium along with the standard reference strain Lactobacillus acidophilus MTCC 10307 (RLAB 4). The lactic acid bacterial isolates including reference strain were Gram positive and rod shaped cells. They were not able to hydrolyze gelatin and were catalase negative. They were tested for gas and acid production from lactose and observations showed that isolates were homo-fermentative; they produced only acid and did not produce any gas during growth. Thus, it can be concluded that, an agricultural waste like banana pseudo stem core, which is rich in sugars, minerals and vitamins could harbor potent lactic acid bacteria which can be used for production of a non-alcoholic (probiotic) beverage by the action of lactic acid bacteria.

\section{References}

Abdul Khalil, H. P. S., Alwani, M. S. and Omar, A. K. M. 2006. Chemical composition, anatomy, lignin distribution, and cell wall structure of Malaysian plant waste fibers:
Cell walls of tropical fibers. Bioresour. 1(2): 220-232.

Aneja, K. R. 2012. Experiments in Microbiology, Plant Pathology, and Biotechnology. New Age International (P) Ltd., New Delhi.

Bardiya, N., Somayaji, D. and Khanna, S. 1996. Biomethanation of banana peel and pineapple waste. Bioresour. Technol. 58: 73-76.

Bernardeau, M., Vernoux, J. P., Henri-Dubernet, S. and Gue' guen, M. 2008. Safety assessment of dairy microorganisms: the Lactobacillus genus. Int. J. Food Microbiol., 126: 278-285.

De Mann, J. C., Rogosa, M. and Sharpe, M. E. 1960, A medium for the cultivation of Lactobacilli. J. Appl. Bacteriol. 23: 130135.

Deepak, S. 1994, Isolation and selection of thermotolerant yeasts for ethanol production. Indian J. Microbiol., 34: 193203.

El-Rahim, A. M. A., Mowafi, I. R., Mohran, M. A. and Darwish, A. M. 2017. Isolation and identification of some lactic acid bacteria from traditional Kareish cheese, butter milk and whey. Egyptian J. Dairy Sci. 45(2): 165-170.

Hammes, W. P., Tichaczek, P. S., Meyer, J., Nes, I. F. and Vogel, R. F. 1992. Characterization of the bacteriocins curvacin A from Lactobacillus curvatus LTH1174 and sakacin $\mathrm{P}$ from L. sake LTH673. System. Appl. Microbiol. 15(3): 460-468.

Isitua, C. C. and Ibeh, I. N. 2010. Novel method of wine production from banana (Musa acuminata) and pineapple (Ananas comosus) wastes. Afr. J. Biotechnol. 9(44): 7521-7524.

Kim, H. Y., Kyung, M. Y., Bok, N. K. and Hong, S. C. 1998. Chemical changes of fruit vegetable juice during mixed culture fermentation of lactic acid bacteria isolated from kimchi and yeast. J. Korean Soc. Food Sci. Nutr. 27: 1065-1070.

Lade, H. S., Chitanand, M. P., Gyananath, G. and Kadam, T. A. 2006. Studies on some properties of bacteriocins produced by Lactobacillus species isolated from agrobased waste. Int. J. Microbiol., 2(1): 44-47. 
Li, K., Fu, S., Zhan, H., Zhan, Y. and Lucia, L. A. 2010. Banana pseudostem chemistry, structure. Bioresour. 5(2): 576-585.

Mayer, F. and Hillebrandt, J. O. 1997. Potato pulp: Microbiological characterization, physical modification, and application of this agricultural waste product. Appl. Microbiol. Biotechnol. 48: 435-440.

Muyanja, C. M. B. K., Narvhus, J. A., Treimo, J. and Langsrud, T. 2003. Isolation, characterization and identification of lactic acid bacteria from bushera: A Ugandan traditional fermented beverage. Int. J. Food Microbiol. 80: 201-210.

Papamanoli, E., Tzanetakis, N., LitopoulouTzanetaki, E., and Kotzekidou, P. 2003. Characterization of lactic acid bacteria isolated from a Greek dryfermented sausage in respect of their technological and probiotic properties. Meat Sci., 65(2): 859-867.

Saira, T., Munawar, M. A. and Khan, S. 2007. Natural fiber reinforced polymer composites. Proceedings of the Pakistan Academy of Sciences. 44(2): 129 -144.

Seelay and Vandemark, P. J. 1970. Microbes in action. A laboratory manual of Microbiology, Tarparcvala sons and Co. Pvt. Ltd., pp. 86-95.

Subrahmanyan, V., Lal, G., Bhatia, D. S., Jain, N. L., Bains, G. S., Srinath, K.V., Anandaswamy, B., Krishna, B. H. and Lakshminarayana, S. K. 1957. Studies of banana stem starch production, yield, physicochemical properties and uses. Jour. Sci. Food Agri. 8(5): 253-261.

Sulochana, M. B., Sharada, B. and Dayanand, A. 2002. Detection and development of Lactobacilli and their bioprocessing features. Biotechnol., Microbes Sustainable Utilization, 30: 239-243.

Suskovic, J., Kos, B., Matosic, S. and Besendorfor, V. 2000. Role of lactic acid bacteria and Bifidobacteria in synbiotic effect. Food Technol. Biotechnol. 39: 227235.

Tamminen, J, T., Palva, S. M., Ryhanem, E. L. and Joutsjoki, V. 2004. Screening of lactic acid bacteria from fermented vegetables by carbohydrate profiling and PCR-ELISA. Appl. Microbiol., 39: 439-442.

Tannock, G. W. 1999. A fresh look at the intestinal microflora in Probiotics: A Critical Review. Wymondham: Horizon Scientific Press. pp. 5-14.

Uma, S., Kalpana, S., Sathiamoorthy, S. and Kumar, V. 2005. Evaluation of commercial cultivars of banana (Musa spp.) for their suitability for the fibre industry. Plant Genetic Resources News Letter. 142: 2935.

Van Loo, S. and Koppejan, J. 2009. The handbook of biomass combustion and cofiring. Earthscan. pp. 79.

Zlatica Kohajdova, Jolana Karovicova and Maria Greifova, 2006. Lactic acid fermentation of some vegetable juices. J. Food Nutri. Res., 45(3): 115-119.

\section{How to cite this article:}

Shriniketan Puranik, K.B. Munishamanna and Sruthy, K.S. 2019. Isolation and Characterization of Lactic Acid Bacteria from Banana Pseudostem. Int.J.Curr.Microbiol.App.Sci. 8(03): 39-47. doi: https://doi.org/10.20546/ijcmas.2019.803.006 